\title{
Applications of Photomorphogenesis Research to Horticultural Systems
}

The photomorphogenesis research program at Clemson Univ. consists of a group of scientists with diverse backgrounds and interests who share a common goal of learning how manipulation of the light environment can be used to regulate plant development. While the program may be considered small in the number of scientists and young in terms of length of existence, some of the research findings have already had an impact on several horticultural industries. An important objective of our work that complements our overall goal is to incorporate innovative ideas into production systems to make them more effective for growing horticultural crops. The success of the "light" program at Clemson Univ. is even more noteworthy because much of the research was done with limited financial support. Funding for the early photomorphogenesis research came through "in-house" grants and incorporating light-related research objectives into existing projects. The Clemson Univ. photomorphogenesis program continues to evolve and supply information to our horticultural and supporting industries and to provide training for a new generation of research scientists.

\section{Photomorphogenesis research program at Clemson Univ.}

The photomorphogenesis research program at Clemson began about 1985, even though important research on photosynthetically active light distribution in peach [Prunus persica (L.) Batsch.] tree canopies had been investigated by a research team led by D.C. Coston in the early 1980s. In 1985, Decoteau collaborated with U.S. Dept. of Agriculture, Agricultural Research Service scientists $M$. Kasperbauer and P. Hunt on the use of variouscolored reflective polyethylene mulches for

Received for publication 16 Oct. 1992. Accepted for publication 1 Nov. 1992. The cost of publishing this paper was defrayed in part by the payment of page charges. Under postal regulations, this paper therefore must be hereby marked advertisement solely to indicate this fact.

Front cover: (clockwise from top left) Young watermelon plants that were treated with end-ofday red (R), far-red (FR), and FR followed by R light, respectively; light-exposure chambers used to treat plants with FR (top) and R (bottom) light; fiber optic system used to directionally expose specific plant organs; field evaluation of colored reflective mulches; experimental liquid spectral filter greenhouse panels at Clemson Univ.; and poinsettia plants grown in chambers fitted with spectral filters (left to right: clear, nonselective filter covered with neutral density shadecloth filter filled with copper sulfate solution; and clear, nonselective filter without shadecloth). plant growth and production. Hunt had previously worked with Kasperbauer on phytochrome regulation of plant development over soils of various colors (Kasperbauer and Hunt, 1987). Results from research with colored mulch suggested that the mulch surface color could induce changes in the plant microclimate (e.g., spectral balance and quantity of light, root-zone temperatures) that could act through natural regulatory systems within the plant to influence plant growth and fruit production (Decoteau et al., 1989,1990). In 1986, nematologist B. Fortnum began a research project investigating the influence of colored mulches and light quality on nematode interactions with roots and plant productivity. Roots of tomato (Lycopersicon esculentum Mill.) plants grown over red mulch contained more larvae per gram of dry root weight than similar plants grown over white mulch (Fortnum et al., 1992). This interaction of mulch color and nematode population should provide insight in nonchemical techniques for nematode control on susceptible crops, such as tomato.

In 1987, Decoteau and Kelly collaborated on the use of reflective colored surfaces for poinsettia (Euphorbia pulcherrima Willd. ex Klotzsch) production in the greenhouse. With the assistance of entomologist P. Adler, they demonstrated that reflective surfaces of various colors altered whitefly [Trialeurodes vaporariorum (Westwood)] population densities. Poinsettias grown over white plastic had fewer immature and adult whiteflies than plants grown on either red or black plastic, suggesting a possible use of colored reflective surfaces for nonchemical insect control (Kelly et al., 1989).

In 1989, Kelly and Decoteau, with Young and J. BUM (agricultural engineers), McMahon (horticulture graduate student), and Pollock (agricultural and biological engineering graduate student), began aresearch project to further develop the technology for using liquid spectral filters in greenhouses. McMahon and Pollock visited L. Mortensen in Norway. Mortensen's earlier research had suggested the potential of spectral filters in plant growth regulation (Mortensen and Stromme, 1987). A model greenhouse system was developed at Clemson Univ. and subsequent research demonstrated that liquid spectral filters could be developed by placing various aqueous dyes (with specific spectral characteristics) in the double-layered acrylic or polycarbonate sheets that are used as greenhouse glazing (Pollock et al., 1990). The work at Clemson Univ. focused on several aqueous dye solutions. These liquid spectral filters served as selective filters for the photomorphogenetic wavelengths of radiation that affect plant morphology (McMahon et al., 1991). They also reduced transmission of the radiative heat component and solar background spectra and, thereby, affected greenhouse cooling requirements (Pollock, 1992; Pollock et al., 1992).

Commercial materials typically used for greenhouse shading and construction subsequently were studied for their spectral distribution properties (McMahon et al., 1990). In addition, rowcovers were investigated for their spectral transmission properties and potential influence on plant development (Friend and Decoteau, 1990). Spunbonded materials generally reduced the blue light transmission, but had no effect on the far-red (FR) : $\operatorname{red}(\mathrm{R})$ ratio. White polyethylene materials increased the relative amounts of FR : R and decreased the blue. Watermelon [Citrullus lanatus (Thunb.) Matsum. \& Nakai] plants exposed to higher FR : R ratios grew taller than plants exposed to smaller ratios (Decoteau and Friend, 1991 a). The taller plants might be more susceptible to lodging after the rowcovers are removed from the field. These results suggest the importance of considering light transmission in developing future rowcover materials for vegetable production.

In 1989, H. Hatt (horticulture graduate student) and Decoteau began to investigate the physiological mechanisms of the end-of-day $R$ and FR regulation of plant growth. Their research goal was to better understand phytochrome-regulated growth of watermelon (Decoteau and Friend, 1991 b). Using a hydroponics growth system, selected light quality treatments were applied to either roots or shoots of watermelon plants (Friend and Decoteau, 1991c). Shoots irradiated with FR light had longer petioles and higher stem and petiole dry weights than the controls. Roots irradiated with FR light also led to increased petiole length andpetiole dry weight. These FR growth responses were reversed with $\mathrm{R}$ light exposure, implicating phytochrome-mediated growth responses. In addition, a fiber optics system was developed to directionally expose specific watermelon plant organs, such as leaves or petioles, to light treatments (Friend and Decoteau, 1991a). FR treatment of adaxial (upper) leaf surfaces promoted acute petiole angles and obtuse leaf angles. FR treatment of abaxial (bottom) leaf surfaces promoted less acute petiole angles and less obtuse leaf angles. These results suggest that light quality photomodulates leaf and petiole growth. In other research, the influence of light quality in transplant production was determined using end-of-day supplemental light in the greenhouse (Decoteau and Friend, 1991c) and copper sulfate filters (Benson, 1992; Clark et al., 1991). Using either end-of-day supplemental fluorescent light (a light source rich in $\mathrm{R}$ wavelengths), end-of-day R light, or day-long copper sulfate-filtered light resulted in compact tomato transplants (a desirable trait in transplant production) with no effect on subsequent fruit yield.

J. John (horticulture graduate student) investigated light regulation of tissue-cultured plantlet development. She observed that yam (Dioscorea alata L.) plantlet growth and

(continued on inside back cover) 


\section{(continued from inside front cover)}

protuber development could be affected by treating the plantlets with end-of-day R or FR light (John, 1990). Recently, A. Saeboe (visiting scholar from Agricultural Univ., Norway) investigated the influence of light quality and $\mathrm{CO}_{2}$ on a birch tissue culture system.

Rajapakse (horticulture postdoctoral fellow) has assumed a leading role in determining the effects of $\mathrm{CuSO}_{4}$ filters on greenhouse plant production and on the plant's biochemical constituents. Initial studies indicated that $\mathrm{CuSO}_{4}$ concentrations as low as $4 \%$ reduced plant height and internode length of chrysanthemum [Dendrathema $\times$ grandiflorum (Ramat.) Kitamura] plants similar to plants treated with chemical growth regulators (Rajapakse and Kelly, 1992). Reduction of plant height and internode length by $\mathrm{CuSO}_{4}$ filters could be reversed by weekly applications of gibberellic acid (GA), suggesting that GA metabolism may be. altered under spectral filters (Rajapakse and Kelly, 1991). In subsequent experiments, they investigated whether phytochrome was the mechanism influencing plant growth when light quality was modified by $\mathrm{CuSO}_{4}$ filters. Their results showed that the height reduction caused by $\mathrm{CuSO}_{4}$ filters was reversed by end-of-day exposure to FR light (Rajapakse et al., 1993). In other studies, they observed that plants grown under $\mathrm{CuSO}_{4}$ filters used less total water. In experiments to determine how light quality affects the plant's biochemical composition, they noticed that light transmitted through $\mathrm{CuSO}_{4}$ filters reduced leaf and stem soluble sugar (sucrose, glucose, and fructose) concentrations along with the starch content of chrysanthemum and rose (Rosa hybrida) plants.

Rajapakse and Kelly, in collaboration with researchers from the Agricultural and Biological Engineering Dept., have begun to correlate plant response under $\mathrm{CuSO}_{4}$ filters with that under currently used light quality characteristics (Rajapakse et al., 1992). When increasing $\mathrm{CuSO}_{4}$ concentrations were used as filtering dyes, commonly used quantitative light quality variables, such as FR : R and phytochrome equilibrium, were not effective in predicting plant growth responses. Their results suggest the importance of presenting complete spectral data of light quality when reporting light quality effects on plant development.

As the general public becomes more concerned about exogenous chemical applications to plants because of unwanted residue in food crops, toxic effects on nontargeted species, and contamination of the environment, interest in using alternative methodology, such as light quality, to regulate plant growth and control disease and insect pests will increase. Researchers studying photomorphogenesis at Clemson will continue to generate new information on light and plant growth and use this new knowledge to develop environmentally sound horticultural systems for the successful production of vegetables, fruits, flowers, and ornamental crops.

\section{Literature Cited}

Benson, J.L. 1992. Effects of spectral filters on bedding plant growth. MS Thesis, Clemson Univ., Clemson, S.C.

Clark, D.G., J.W. Kelly, and D.R. Decoteau. 1991. The influence of end-of-day red and far-red light on potted roses. J. Environ. Hort. 9: 123-127.

Decoteau, D.R. and H.H. Friend. 1991a. Plant responses to wavelength selective mulches and row covers: A discussion of light quality effects on plants. Proc. Natl. Agr. Plastics Congr. 23:46-51.

Decoteau, D.R. and H.H. Friend. 1991b. Phytochrome-regulated growth of young watermelon. J. Amer. Soc. Hort. Sci. 116:512-515.

Decoteau, D.R. and H.H. Friend. 1991c. Growth and subsequent yield of tomatoes following end-of-day light treatment of transplants. HortScience 26:1528-1530.

Decoteau, D.R., M.J. Kasperbauer, and P.G. Hunt. 1989. Mulch color affects yield of fresh market tomatoes. J. Amer. Soc. Hort. Sci. 114:216-220.

Decoteau, D.R., M.J. Kasperbauer, and P.G. Hunt 1990. Bell pepper plant development over mulches of diverse colors. HortScience 25:460462.

Fortnum, B.A., D.R. Decoteau, and M.J. Kasperbauer. 1992. Mulch surface color on simulated planting beds affects root-knot of tomato J. Nematol. 24:590. (Abstr.)

Friend, H.H. and D.R. Decoteau. 1990. Transmission properties of selected row cover materials and implications in early plant development. Proc. Natl. Agr. Plastics Congr. 22:1-6.

Friend, H.H. and D.R. Decoteau. 1991a. Photomodulation of watermelon plant growth as affected by light quality. HortScience 26:745. (Abstr.)

Friend, H.H. and D.R. Decoteau. 1991b. Root and shoot perception of light quality and photomorphogenic growth of watermelon. HortScience 26:737. (Abstr.)

John, J.L. 1990. Light and plant growth regulator effects on yam (Dioscorea alata L.) growth and development. MS Thesis, Clemson Univ., Clemson, S.C.

Kaspcrbauer, M.J. and P.G. Hunt. 1987. Soil color and surface residue effects on seedling light environment. Plant \& Soil 97:295-298.
Kelly, J.W., P. Adler, D.R. Decoteau, and S. Lawrence. 1989. Colored reflective surfaces to control whiteflv on poinsettia. HortScience 24:1045.

McMahon, M.J., J.W. Kelly, and D.R. Decoteau. 1990. Spectral transmittance of selected greenhouse construction and nursery shading materials. J. Environ. Hort. 8:118-121.

McMahon, M.J., J.W. Kelly, D.R. Decoteau, R.E. Young, and R.K. Pollock. 1991. Growth of Dendranthema xgrandiflorum (Ramat.) Kitamura under various spectral filters. J. Amer. Soc. Hort. Sci. 116:950-954.

Mortensen, L.M. and E. Stromme. 1987. Effects of light quality on some greenhouse crops. Scientia Hort. 33:27-36.

Pollock, R.K. 1992. Cooling characteristics of a greenhouse polycarbonate fluid roof. MS Thesis, Clemson Univ., Clemson, S.C.

Pollock, R.K., R.E. Young, J.M. Bunn, and W.H. Allen. 1992. Cooling characteristics of a fluid roof panel. Amer. Soc. Agr. Eng. Paper 924074. Amer. Soc. Agr. Eng., St. Joseph, Mich.

Pollock, R.K., R.E. Young, M.J. McMahon, and J.W. Kelly. 1990. Liquid spectral filtering for greenhouses: Regulation of photomorphogenesis in plants. Amer. Soc. Agr. Eng. Paper 904036. Amer. Soc. Agr. Eng., St. Joseph, Mich.

Rajapakse, N.C. and J.W. Kelly. 1991. Influence of $\mathrm{CuSO}_{4}$ filters and exogenous gibberellic acid on growth of Dendranthema grandiflorum (Ramat.) Kitamura 'Bright Golden Anne'. J. Plant Growth Regulat. 10:207-214.

Rajapakse, N.C. and J.W. Kelly. 1992. Regulation of chrysanthemum growth by spectral filters. J. Amer. Soc. Hort. Sci. 117:481-485.

Rajapakse, N.C., M.J. McMahon, and J.W. Kelly. 1993. End of day far-red light reverses the height reduction of chrysanthemums induced by copper sulfate spectral filters. Scientia Hort. 53:249259.

Rajapakse, N.C., R.K. Pollock, M.J. McMahon, J.W. Kelly, and R.E. Young. 1992. Interpretation of light quality measurements and plant response in spectral filter research. HortScience 27:1208-1211.

Dennis R. Decoteau,

Heather A. Hatt, John W. Kelly, Margaret J. McMahon, and Nihal Rajapakse Dept. of Horticulture Poole Agricultural Center Box 340375 Clemson Univ. Clemson, SC 29634-0375

Roy E. Young and Robert K. Pollock Dept. of Agricultural and Biological Engineering

McAdams Hall Clemson Univ. Clemson, SC 29634 